\title{
ANTIOXIDANT AND ANTIMICROBIAL ACTIVITIES OF THYME AND CLOVE ESSENTIAL OILS AND APPLICATION IN MINCED BEEF
}

\author{
HATICE ZENGIN and AYSE HANDAN BAYSAL ${ }^{1}$ \\ Department of Food Engineering, Izmir Institute of Technology, Urla, Izmir 35437, Turkey
}

${ }^{1}$ Corresponding author.

TEL: +90-232-7506187;

FAX: +90-232-7506196;

EMAIL: handanbaysal@iyte.edu.tr

Received for Publication March 5, 2014

Accepted for Publication June 28, 2014

doi:10.1111/jfpp. 12344

\begin{abstract}
In this study, thyme and clove essential oils (EOs) were studied for their chemical composition, antioxidant, antiradical and antibacterial activity and application in ground beef. Carvacrol (75.27\%) and eugenol (75.2\%) were detected by gas chromatography-mass spectrometry analysis as the main components of thyme and clove EOs, respectively. Broth microdilution method showed all bacteria inhibited by the EOs, while Shewanella putrefaciens and Listeria innocua were the most resistant bacteria to thyme and clove EOs, respectively. EO treatment restricted the growth of artificially inoculated Salmonella typhimurium and native Coliforms in the ground beef. Antioxidant activity determined by ferric-reducing antioxidant power and 1,1 diphenyl-2-picrylhydrazyl methods demonstrated that clove EO had higher in vitro antioxidant activity than thyme EO. Similar results were obtained in ground beef application using 2-thiobarbituric acid value. EOs of clove (2MIC) exerted remarkable higher antioxidant activity in ground beef than EOs of thyme (4MIC), which represent valid alternative antioxidant in meat products.
\end{abstract}

\section{PRACTICAL APPLICATIONS}

Plant essential oils (EOs) serve as a "safe" alternative to chemical or synthetic antimicrobials and antioxidants to struggle with the foodborne pathogens or spoilage organisms, inhibiting lipid oxidation and thus extending shelf life. Antioxidant activity determined by ferric-reducing antioxidant power and 1,1 diphenyl-2picrylhydrazyl methods showed that clove EO had higher in vitro antioxidant activity than thyme EO. Results obtained using 2-thiobarbituric acid value in ground beef application were found similar. EOs of clove (2MIC) exerted higher antioxidant activity in ground beef than EOs of thyme (4MIC). Therefore, EOs could be a valid alternative antioxidant in meat products.

\section{INTRODUCTION}

Natural products such as plant essential oils (EOs) have uses in human health such as functional food, food additives, medicine, nutritional supplements and cosmetic manufacturing. Antioxidants are effective for inhibiting different human diseases due to their antiradical, antioxidant and antimicrobial properties. Therefore, investigation of bioactive compounds particularly polyphenols from natural plant sources including herbs and spices has an increasing trend. Plant EOs have antimicrobial, antioxidant and antimutagenic activities, and potential beneficial effects on certain health conditions. These generally recognized as safe nature substances inhibited lipid oxidation in foods, thereby serving as natural additives in foods and food products (Burt 2004; FDA 2013).

Thyme (Thymus sp.) and clove (Syzygium aromaticum) EOs are of much attention due to their high content and wide spectrum of phenolic compounds, antimicrobial and antioxidant properties, and potential for use in meat and meat products (Gutierrez et al. 2008; Barbosa et al. 2009; Gutierrez et al. 2009; Jayasena and Jo 2013; Bensid et al. 2014). The use of EOs is reported in the literature to improve shelf life of meat (Lucera et al. 2012; Jayasena and Jo 2013). 
To the best of our knowledge, there is no data on antioxidant, antiradical and antimicrobial activities of thyme and clove EOs in vitro and on their antimicrobial and antioxidant effects in a real food system such as minced beef. The purpose of this study was to identify the main phenolic compounds present in thyme and clove EOs and determine their antioxidant and antimicrobial effects by in vitro and in vivo approaches. Total antioxidant activity was determined by ferric-reducing antioxidant power (FRAP) and 1,1 diphenyl-2-picrylhydrazyl (DPPH) methods. The composition and total phenolic content (TPC) were analyzed by gas chromatography-mass spectrometry (GC-MS) analysis and Folin-Ciocalteu assay, respectively. The antibacterial activity was evaluated by inhibition of in vitro cell cultures of meat borne spoilage and pathogen bacteria, namely, Staphylococcus aureus, Listeria innocua, Carnobacterium divergens, Escherichia coli O157:H7, Salmonella typhimurium, Shewanella putrefaciens and Serratia liquefaciens. Antimicrobial and antioxidant effects of the EOs in minced beef were determined by the evaluation of 2-thiobarbituric acid (TBA) and color parameters and by the efficacy to eliminate or control artificially inoculated Sa.typhimurium and its native microbial flora, respectively, during storage under refrigeration (4C) aerobically.

\section{MATERIALS AND METHODS}

\section{EOs}

Commercial food-grade thyme and clove EOs were purchased from native producer. All the chemicals used were of analytical grade and they were purchased from Sigma Chemical Co. (St. Louis, MO). Different concentrations of EOs were prepared in ethanol daily. The final concentration of ethanol was not more than $1 \%$ in broth. Because dimethyl sulphoxide (DMSO) is toxic and cannot be used in food systems, ethanol was chosen as solvent (Burt et al. 2007).

\section{Microbial Strains}

Pathogenic, nonpathogenic and spoilage-related bacteria were handled during the study. Spoilage-related bacteria were obtained from the United States Department of Agriculture Agricultural Research Service Culture Collection (NRRL). Others were obtained from the Department of Food Engineering, Izmir Institute of Technology. Grampositive and -negative bacterial strains used in the study (their origins) were St. aureus RSSK 01009 (clinical), L. innocua NRRL B-33314 (turkey/ham, deli sticks), C. divergens NRRL B-14830 (minced beef), E. coli O157:H7 ATCC 700728 (unknown), Sa.typhimurium CCM5445 (unknown), Sh. putrefaciens NRRL B-951 (unknown) and
Se. liquefaciens NRRL B-41553 (ground beef). E. coli O157:H7, Sa. typhimurium, St. aureus and L. innocua strains were grown in nutrient broth (NB). Sh. putrefaciens and Se. liquefaciens were first propagated in tryptic soy broth, whereas $C$. divergens was grown in YG broth. After first propagation all bacteria were transferred to NB and growth was observed. NB medium was used for all the experiments.

\section{Bacterial Suspensions}

Cultures were grown in appropriate media and incubation conditions. Then bacterial suspensions were adjusted equivalent to 0.5 McFarland standard by using a Densitometer (DEN-1, HVD Life Sciences, Vienna, Austria) (approximately $7-8 \log _{10} / \mathrm{mL}$ ) and one more 10 -fold dilution was performed in broth medium.

\section{Determination of Antimicrobial Activity by Broth Micro- and Macrodilution Methods}

For broth microdilution, $20 \mu \mathrm{L}$ of bacterial suspension was added to the wells of a sterile 96-well microtiter plate containing $180 \mu \mathrm{L}$ of twofold diluted EOs. Control wells were prepared with culture medium inoculated with bacterial suspension and also EOs without inoculation. Plates were incubated for $24 \mathrm{~h}$ and turbidity was determined by a microplate reader (Varioskan Flash, Thermo) at $600 \mathrm{~nm}$ with 30-min interval (Klančnik et al. 2010). After the incubation period, $100 \mu \mathrm{L}$ of samples was taken from each wells and spread on agar plates to check the growth of bacteria. The MICs of EOs were recorded as the lowest concentration where no viability was observed in the wells of 96-microwell plates after incubation for $24 \mathrm{~h}$. For broth macrodilution (Klančnik et al. 2010), $100 \mu \mathrm{L}$ of bacterial suspensions was inoculated to $900 \mu \mathrm{L}$ of growth media already containing desired concentration of EOs and incubated by shaking for $24 \mathrm{~h}$ at appropriate incubation temperatures. After $24 \mathrm{~h}$ $100 \mu \mathrm{L}$ of sample was directly spread on agar plates and growth of colonies was checked after incubation for 24-48 h. The absence of colonies on plates of a treatment was considered as MIC values.

\section{GC-MS Analysis}

GC-MS analysis was carried out in an Agilent 6890 gas chromatograph interfaced to an Agilent 5973N mass selective detector MSD (Agilent Technologies, Palo Alto, CA) according to the method suggested by Ramos et al. (2012). The GC was equipped with a (5\%-phenyl)-methyl polysiloxane HP-5MS column (30 m length $\times 0.25 \mathrm{~mm}$ internal diameter $\times 0.25 \mu \mathrm{m}$ film thickness). Helium was used as the carrier gas at a flow rate of $1 \mathrm{~mL} / \mathrm{min}$ constant flow. The oven temperature was programmed from $45 \mathrm{C}$ 
(hold for $1 \mathrm{~min}$ ) to $250 \mathrm{C}(5 \mathrm{~min}$ ) at $5 \mathrm{C} / \mathrm{min}$ in a $47-\mathrm{min}$ total running time. One hundred to four hundred atomic mass unit was used as scanning mass range. Identification of components in EOs was carried out by the comparison of the mass spectra characteristic features with the NIST 05 mass spectral library.

\section{Determination of TPC}

TPC was determined by Folin-Ciocalteu assay. Briefly, diluted samples were mixed with Folin-Ciocalteu's reagent (1/10 in distilled water) and left to stand $2-3 \mathrm{~min}$ at room temperature. After adding sodium carbonate solution $(7.5 \%$ $\mathrm{w} / \mathrm{v}$ ) to the mixture, tubes were allowed to stand for $60 \mathrm{~min}$ in a dark place at room temperature, then the absorbance of each solution was read against the blank at $765 \mathrm{~nm}$. The same procedure was applied to gallic acid with different concentrations to obtain a calibration curve. Results were expressed as milligram gallic acid equivalents (GAE)/mL (Slinkard and Singleton 1977).

\section{Determination of Total Antioxidants by FRAP Method}

FRAP was performed according to Thaipong et al. (2006). The fresh working FRAP solution was prepared by mixing $10 \mathrm{~mL}$ of acetate buffer $(300 \mathrm{mM}, \mathrm{pH} 3.6), 1 \mathrm{~mL}$ of TPTZ (10 mM 2, 4, 6-tripyridyl-striazine) and $1 \mathrm{~mL}$ of $\mathrm{FeCl}_{3} \cdot 6 \mathrm{H}_{2} \mathrm{O}$ solution and then warmed at $37 \mathrm{C}$ before use. Then, $150 \mu \mathrm{L}$ of diluted samples was allowed to react in FRAP solution in a $3-\mathrm{mL}$ total volume for $30 \mathrm{~min}$ in the dark condition. Readings were then taken at $593 \mathrm{~nm}$ and results were expressed as milimol Trolox equivalent per $\mathrm{mL}$.

\section{Determination of Antiradical Activity by DPPH Method}

The DPPH radical was determined by the method with some modifications (Ojeda-Sana et al. 2013); briefly, $20 \mu \mathrm{L}$ of each sample in triplicate and six different concentrations and $180 \mu \mathrm{L}$ of DPPH solution $(160 \mathrm{mM})$ in ethanol was added to a well in a 96-well flat bottom microtitration plate. A DPPH solution was used as blank sample. Plate was incubated for $24 \mathrm{~h}$ and absorbance was measured at $515 \mathrm{~nm}$ with 10 -min interval. The antioxidant activity of the tested samples, expressed as percentage inhibition of DPPH, was calculated according to the following formula where $A b$ is absorbance of blank sample and $A s$ is absorbance of a tested sample at the end of the reaction (Delgado Adámez et al. 2012; Ramos et al. 2012; Ojeda-Sana et al. 2013).

$$
I C(\%)=([A b-A s] / A b) \times 100
$$

Percentage inhibition after where the reaction gone to completion ("plateau") was plotted against concentration and a linear regression was applied to obtain the $\mathrm{IC}_{50}$ value (the concentration of essential oil inhibiting bacterial growth by 50\%) (Schwarz et al. 2001).

\section{Antimicrobial Effect of EOs in Minced Meat}

Sa. typhimurium bacterial suspension was prepared using McFarland standard and further diluted to yield a final concentration of $4 \mathrm{log} / \mathrm{g}$. After inoculation and homogenization in a stomacher of meat samples, thyme and clove EOs were added at MIC $\times 2$ and MIC $\times 4$ values. Afterward, mixtures were homogenized again. Minced beef samples were then divided into $10 \mathrm{~g}$ of portion for each sampling time and for each analysis. Samples were kept at $4 \mathrm{C}$ and examined during 9 days.

\section{Microbiological Analyses}

Microbiological analyses of samples included the determination of the population of Sa.typhimurium, aerobic mesophilic microorganism (AMM), psychrotrophic microorganisms, coliform, yeasts and molds. Analyses were carried out at 3-day intervals up to the ninth day at $4 \mathrm{C}$. All of microbial counts were expressed as $\log _{10}$ colony-forming units per $g$ of sample. The media used in the study were obtained from Difco, BD, Dickinson. At each sampling time, $10 \mathrm{~g}$ of samples was homogenized in a stomacher bag for $2 \mathrm{~min}$ in $90 \mathrm{~mL}$ of sterile buffered peptone water (BPW). Serial dilutions were made in BPW and used for enumeration of microorganisms. Brilliant green agar and bismuth sulfite agar were used to evaluate the microbial count of Sa. typhimurium after $24 \mathrm{~h}$ incubation at 37C. Coliforms were determined using the plate counting method on violet red bile agar as a medium after $24 \mathrm{~h}$ of incubation at $37 \mathrm{C}$. AMM was determined on plate count agar (PCA) incubated at $30 \mathrm{C}$ for $48 \mathrm{~h}$. Potato dextrose agar was used to determine yeasts and molds after $48 \mathrm{~h}$ of incubation at 25C. Determination of psychrotrophic microorganisms was carried out on PCA with 10-day incubation at 4C.

\section{Determination of Lipid Oxidation}

Lipid oxidation was measured by the TBA method as described by Djenane et al. (2012). Five grams of minced meat samples was taken and mixed well with $10 \mathrm{~mL}$ of trichloroacetic acid (10\%). Samples were then centrifuged at $10,000 \mathrm{rpm}$ for $30 \mathrm{~min}$ at $5 \mathrm{C}$, and supernatants were filtered through quantitative paper. Two milliliters of filtered supernatant was mixed with $2 \mathrm{~mL}$ of thiobarbituric acid $(20 \mathrm{mM})$ (99\%, Sigma); tube contents were mixed well with vigorous vortexing and incubated at $97 \mathrm{C}$ for $20 \mathrm{~min}$ in a boiling 
water bath. After incubation tubes were cooled immediately and absorbance was measured at $532 \mathrm{~nm}$, the average of three absorbance values was used to determine the oxidative stability.

\section{Color Evaluation}

Color was instrumentally measured by $L^{*}, a^{*}$ and $b^{*}$ system using Minolta CR400 (Tokyo, Japan) colorimeter. The instrument was first standardized against a white reference plate. Five measurements were then taken from each sample. The colorimeter directly calculated three color features of $L^{\star}$ (lightness), $a^{\star}$ (red-green component) and $b^{\star}$ (yellow-blue component).

\section{Statistical Analysis}

All the analysis were carried out in triplicate and the experimental results obtained were expressed as means \pm standard deviation. Statistical analysis of the data was made using analysis of variance (Minitab 16, Minitab Inc., Coventry, UK). Means with a significant difference $(P<0.05)$ were compared using Tukey's test.

\section{RESULTS AND DISCUSSION}

\section{GC-MS Analysis of EOs}

The chemical compositions of EOs from thyme and clove were determined by comparing the relative retention times and the mass spectra of oil components with mass spectra from data library. The EOs were characterized by one or two dominant components that are listed according to their retention time and percentage contribution (Table 1).

The GC-MS analyses resulted in the identification of 18 components of thyme EO (Table 1). The major components of thyme EO determined by GC-MS were carvacrol (75.27\%) followed by cymene (7.84\%), thymol (4.51), $\gamma$-terpinene $(2.96 \%)$ and borneol (1.44\%). The others comprise terpinene, terpineol, limonene, linalool and eucalyptol (Table 1). There is a great variability and diversity of chemical composition of Thymus species due to differences in origin, vegetative cycle and climatic conditions, seasonal and soil variations (Baydar et al. 2004; Sokmen et al. 2004; Tepe et al. 2005; Safaei-Ghomi et al. 2009; Verma et al. 2010; Ait-Ouazzou et al. 2011). Some thymus oils are characterized by the increased percentages of thymol, carvacrol, borneol, linalool or $\alpha$-terpineol (Tepe et al. 2005). The high carvacrol content followed by cymene, thymol, $\gamma$-terpinene and borneol, respectively, is in good agreement with the findings of chemical composition of Iran origin thyme oil (Safaei-Ghomi et al. 2009). Our findings also showed a
TABLE 1. COMPONENTS OF THYME AND CLOVE EOS DETERMINED BY GC-MS ANALYSES

\begin{tabular}{|c|c|c|c|}
\hline & Compound & Compound R. T. (min) & $\%$ \\
\hline \multirow[t]{18}{*}{ Thyme EO } & Carvacrol & 17.623 & 75.27 \\
\hline & Cymene & 9.643 & 7.84 \\
\hline & Thymol & 17.248 & 4.51 \\
\hline & $\gamma$-Terpinene & 10.632 & 2.96 \\
\hline & Borneol & 13.751 & 1.44 \\
\hline & $\beta$-Bisabolene & 22.808 & 1.33 \\
\hline & $\alpha$-Terpinene & 9.409 & 1.25 \\
\hline & $\beta$-Murcene & 8.687 & 1.10 \\
\hline & 4-Terpineol & 14.079 & 0.9 \\
\hline & Caryophyllene & 20.649 & 0.85 \\
\hline & $\alpha$-Pinene & 7.126 & 0.60 \\
\hline & D-limonene & 9.76 & 0.469 \\
\hline & Linalool & 11.827 & 0.39 \\
\hline & $\alpha$-Terpinolene & 11.488 & 0.27 \\
\hline & Camphene & 7.522 & 0.25 \\
\hline & $\alpha$-Phellandrene & 9.058 & 0.15 \\
\hline & Eucalyptol & 9.851 & 0.15 \\
\hline & 1-Octen-3-ol & 8.378 & 0.138 \\
\hline \multirow[t]{6}{*}{ Clove EO } & Eugenol & 19.103 & 75.20 \\
\hline & Benzyl salicylate & 30.78 & 14.75 \\
\hline & Propylene glycol & 3.126 & 6.02 \\
\hline & $\beta$-Caryophyllene & 20.653 & 3.21 \\
\hline & $\alpha$-Caryophyllene & 21.505 & 0.69 \\
\hline & Caryophyllene oxide & 24.642 & 0.122 \\
\hline
\end{tabular}

EO, essential oil; GC-MS, gas chromatography-mass spectrometry.

good relation with the studies associated with EOs of Turkish origin Thymus species (Baydar et al. 2004; Sokmen et al. 2004). Most of the identified components have also previously been reported as major components of thyme EOs from Tunisian (Hosni et al. 2013), Sicilian (Napoli et al. 2010) and Greek origins (Economou et al. 2011).

Clove EO consists of eugenol (75.2\%), benzyl salicylate (14.74\%), propylene glycol (6.02\%) and also $\beta$ caryophyllene $(3.21 \%)$ (Table 1). Clove EOs have different origins extracted by different methods and have been analyzed by various researchers. Eugenol seems to have the highest proportion of tested clove EOs as it was observed from our results. Besides eugenol, eugenol acetate and $\beta$-caryophyllene are the major constituents (Martini et al. 1996; Dorman et al. 2000; Lee and Shibamoto 2001; Guan et al. 2007). GC-MS results differ in the presence and the amount of benzyl salicylate from the literature. The variation in EO composition may be caused by ecological and geographical distribution and also climatic and soil variation condition.

\section{Antimicrobial Activity}

Thyme and clove EOs were examined according to their antimicrobial activities using broth microdilution and macrodilution assays. A wide range of concentration of EO 
TABLE 2. ANTIMICROBIAL ACTIVITY OF EOS EXPRESSED AS MIC (\%) DETERMINED BY BROTH DILUTION ASSAYS

\begin{tabular}{|c|c|c|c|c|}
\hline \multirow[b]{2}{*}{ Bacteria } & \multicolumn{2}{|c|}{ Thyme EO (\% v/v) } & \multicolumn{2}{|c|}{ Clove EO (\% v/v) } \\
\hline & Conc. ranges & MIC & Conc. ranges & MIC \\
\hline \multicolumn{5}{|l|}{ Gram-positive bacteria } \\
\hline Staphylococcus aureus & $2-0.03$ & 0.05 & $2-0.03$ & 0.5 \\
\hline Carnobacterium divergens & $2-0.03$ & 0.06 & $2-0.03$ & 1 \\
\hline Listeria innocua & $2-0.03$ & 0.125 & $2-0.03$ & 2 \\
\hline \multicolumn{5}{|l|}{ Gram-negative bacteria } \\
\hline Shewanella putrefaciens & $2-0.03$ & 0.25 & $2-0.03$ & 1 \\
\hline Serratia liquefaciens & $2-0.03$ & 0.06 & $2-0.03$ & 0.5 \\
\hline Escherichia coli O157:H7 & $2-0.03$ & 0.05 & $2-0.03$ & 0.5 \\
\hline Salmonella typhimurium & $2-0.03$ & 0.05 & $2-0.03$ & 1 \\
\hline
\end{tabular}

$\mathrm{EO}$, essential oil; MIC, minimum inhibitory concentration. was examined by considering the findings in the literature. Results showed obviously that antimicrobial effects of the plant EOs were concentration dependent for all tested bacteria (Table 2). Twenty-four hours of observation of bacterial growth indicated that the MIC values were $0.05 \%$ for all St. aureus, E. coli O157:H7 and Sa. typhimurium for thyme EOs as it is shown in Table 2. Sh. putrefaciens was the most resistant bacteria to thyme EOs with a MIC value of $0.25 \%$. In general, food spoilage organisms were observed to be more resistant to thyme EO than foodborne pathogen organisms. Se. liquefaciens and C. divergens have the MIC value of $0.06 \%$ for thyme EO, whereas $L$. innocua was the most resistant one with the MIC value of $0.125 \%$ among all the tested bacteria. It was determined that thyme EO was highly effective on gram-negative bacteria except from Sh. putrefaciens, and especially foodborne pathogens with a MIC value of $0.05 \%$. Clove bud EO seemed to be effective on both gram-positive and negative bacteria within the range of MIC values between 0.5 and 2.0\%. Among the tested bacteria St. aureus and E. coli O157:H7 were the most sensitive. MIC values of these strains were 0.05 and $0.5 \%$ for thyme and clove EO, respectively.

\section{TPC}

TPCs of EOs were determined by Folin-Ciocalteu assay. Results were calculated using the equation obtained from the gallic acid calibration curve and expressed as mg GAE/ $\mathrm{mL}$. TPC of EOs is presented in Table 3. As it was seen from the table, clove EOs had the highest content of total phenols with $635.327 \mathrm{mg} \mathrm{GAE} / \mathrm{mL}$. Thyme EO was seen to be a less rich source of total phenols. Viuda-Martos et al. (2010), Wang et al. (2008) and Gülçin et al. (2004) also demonstrated that clove bud EO had high phenolic content compared with other EOs like thyme EOs (Gülçin et al. 2004; Wang et al. 2008; Viuda-Martos et al. 2010).

\section{Antioxidant Activity by FRAP and DPPH Method}

Total antioxidant activities of EOs were determined by both FRAP and DPPH methods (Table 3). Antioxidant activity measured by FRAP method was expressed as millimol Trolox equivalent per $\mathrm{mL}$ and calculated using Trolox calibration curve. The ability of EOs was investigated using DPPH assay to observe the ability to act as donors of hydrogen atoms or electrons for the transformation of DPPH into its reduced form DPPH (Ojeda-Sana et al. 2013). Results were expressed as 50\% of inhibition of DPPH and were represented in Table 3. EOs were able to change the stable violet color of DPPH into yellow-colored DPPH, reaching 50\% of reduction with $\mathrm{IC}_{50}$ value changing from 0.14 to $9.88 \mu \mathrm{L} /$ $\mathrm{mL}$. Both results obtained from FRAP and DPPH assays showed nearly the same outcome. Clove EO showed the higher antioxidant activity than thyme EO (Table 3 ). Some authors also reported that there were differences in the results obtained from these two assays (Gourine et al. 2010; Politeo et al. 2010). It is difficult to assess the antioxidant activity of a sample referring to a single method as the interpretation of the activity may require a combination of different methods. But it is obvious that it is difficult to
TABLE 3. THE TOTAL PHENOLIC CONTENTS AND ANTIOXIDANT ACTIVITIES OF EOS

\begin{tabular}{llll}
\hline \multirow{2}{*}{$\begin{array}{l}\text { Sample } \\
\text { Total phenolic content (GAE } \\
\mathrm{mg} / \mathrm{mL})\end{array}$} & Antioxidant activity & \\
\cline { 3 - 4 } & FRAP $(\mathrm{mmol}$ Trolox $/ \mathrm{mL})$ & $\mathrm{DPPH}\left(\mathrm{IC} C_{50} \mu \mathrm{L} / \mathrm{mL}\right)$ \\
\hline Clove & $30.5576 \pm 8.62$ & $2,150.72 \pm 47.03$ & $9.88 \pm 0.75$ \\
\hline & $635.327 \pm 11.71$ & $4,357.45 \pm 28.83$ & $0.14 \pm 0.02$ \\
\hline
\end{tabular}

$\mathrm{DPPH}, 1,1$ diphenyl-2-picrylhydrazyl; EO, essential oil; FRAP, ferric-reducing antioxidant power; GAE, gallic acid equivalent. 

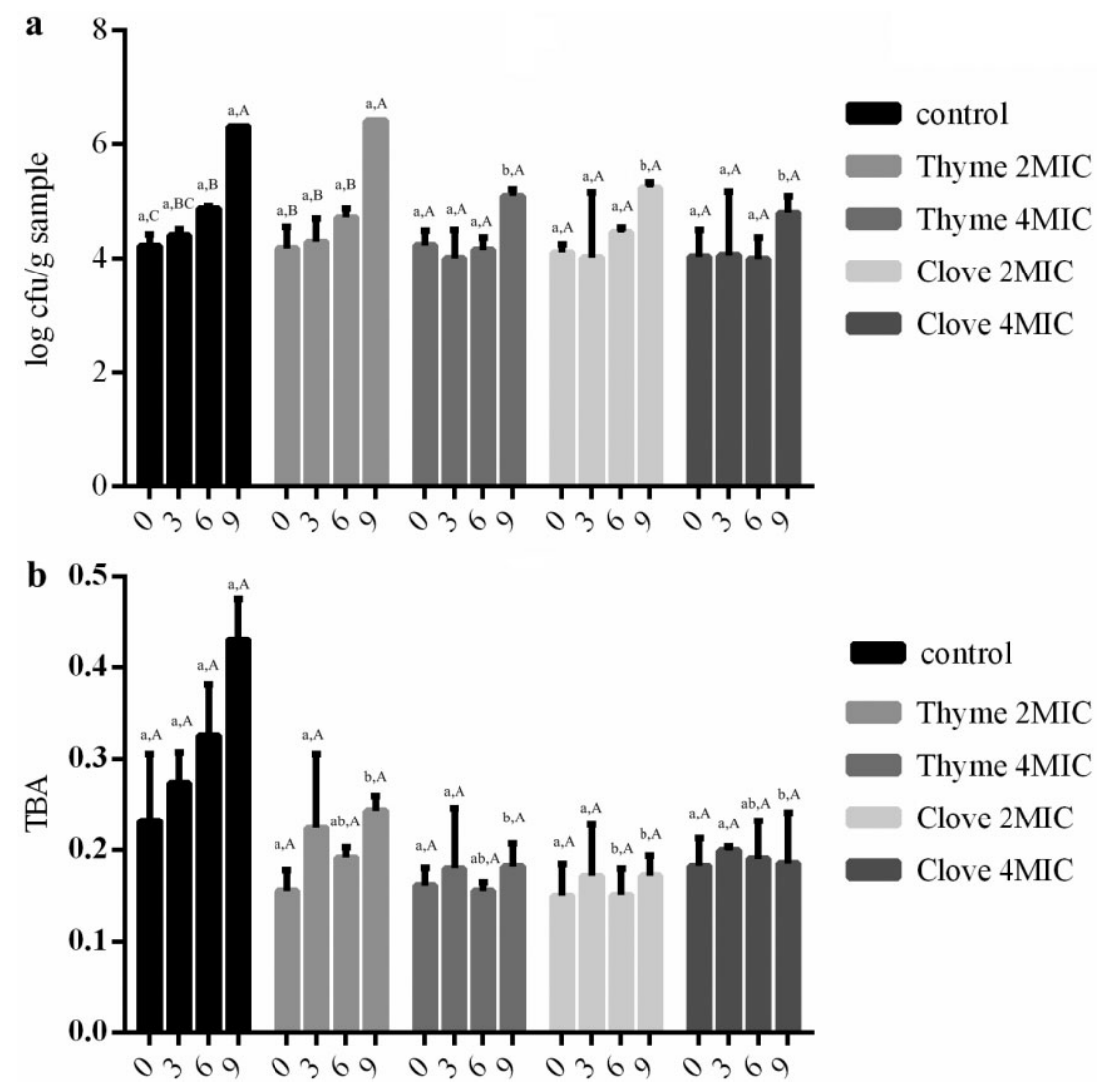

FIG. 1. (a) CHANGE IN

SALMONELLA TYPHIMURIUM INOCULATED TO GROUND BEEF SAMPLES DURING STORAGE TIME AT +4C

(b) Changes in 2-thiobarbituric acid (TBA) values of minced beef samples during storage at $+4 C$. Data represent means \pm standard deviation, $n=3$. Bars with different letters $(\mathrm{a}, \mathrm{b})$ indicate significant difference at $P<0.05$ within each storage time; $\mathrm{A}-\mathrm{C}$ indicate significant difference at $P<0.05$ within each treatment. compare the results of many different methods as it was shown in this study.

When the relation between TPC and antioxidant activities was compared, phenolic content gives antioxidant activity to clove bud EO.

\section{Antimicrobial Effect of EOs in Minced Beef}

The effect of thyme and clove EOs with 2MIC and 4MIC values on the growth of Sa.typhimurium in minced meat samples stored at 4C for 9 days was investigated (Fig. 1a). $2 \mathrm{MIC}$ and $4 \mathrm{MIC}$ values were used as these were below the EO levels, which subsequently not affect the sensorial quality of the meat. Four log cfu/g (low inoculum level) inoculations (Flessa et al. 2005; Simpson et al. 2008; Petkar et al. 2011; Blessington et al. 2012) was performed to each sample. Inoculum level can influence survival of bacteria in some foods (Uhart et al. 2006, Hayouni et al. 2008, Solomakos et al. 2008); however, in this study it was not aimed to assess the impact of inoculum level on survival of Sa.typhimurium inoculated. The number of the Sa. typhimurium did not change significantly during 3 days of storage except a slight increase in control and thyme (2MIC) treated samples (Fig. 1a). At the end of 9-day storage period, significant $(P<0.05)$ difference was detected in the number of Sa.typhimurium between control and thyme (4MIC), clove (2MIC and 4MIC) treated samples. When the number of Sa.typhimurium increased to $6 \mathrm{log} / \mathrm{g}$ in the control sample, the number of the pathogen was $\sim 5$ $\mathrm{log} / \mathrm{g}$ in both thyme (4MIC) and clove (2MIC) treated samples (Fig. 1a). Clove (4MIC) treated sample represented only $0.77 \mathrm{log}$ increase in the number of Sa.typhimurium after 9 days. The results indicated that clove (4MIC) EO had more antimicrobial effect $(P<0.05)$ on Sa.typhimurium than thyme $\mathrm{EO}$ even with $4 \mathrm{MIC}$ value.

The effect of thyme and clove EOs with 2MIC and 4MIC values on AMM was also examined during 9 days of storage (Table 4). The minced meat samples showed a high initial AMM as seen in Table 4. The initial AMM was almost the same for all samples approximately $7 \log \mathrm{cfu} / \mathrm{g}$, indicating high contamination level for aerobic plate count for fresh meat (ICMSF 1986). During the time periods AMM showed an increase of up to $11 \mathrm{log} / \mathrm{g}$ except the clove EO (4MIC) treated sample. At the end of storage for 9 days, AMM increased up to $10 \mathrm{log} \mathrm{cfu} / \mathrm{g}$ for clove EO (4MIC) treated sample. There was a $1 \log$ cycle difference between the control and other treated samples and clove (4MIC) treated sample (Table 4).

Coliform was also determined for control- and EO-treated samples (Table 4). The initial TCC was almost the same for all groups of samples (Table 4). During the 
TABLE 4. CHANGE IN AEROBIC MESOPHILIC COUNT OF GROUND BEEF SAMPLES DURING STORAGE AT 4C

\begin{tabular}{|c|c|c|c|c|c|}
\hline & \multirow[b]{2}{*}{ Samples } & \multicolumn{4}{|c|}{ Storage time (days) } \\
\hline & & 0 & 3 & 6 & 9 \\
\hline \multirow[t]{5}{*}{ Aerobic mesophiles (log cfu/g) } & Control & $7.28 \pm 0.11^{\mathrm{a}, \mathrm{B}}$ & $8.43 \pm 0.29^{a, B}$ & $9.44 \pm 0.62^{a, A B}$ & $11.72 \pm 0.66^{\mathrm{a}, \mathrm{A}}$ \\
\hline & Thyme-2MIC & $7.19 \pm 0.03^{a, c}$ & $8.16 \pm 0.03^{a, B C}$ & $9.60 \pm 0.31^{a, B}$ & $11.86 \pm 0.53^{\mathrm{a}, \mathrm{A}}$ \\
\hline & Thyme-4MIC & $7.18 \pm 0.15^{a, c}$ & $8.43 \pm 0.10^{a, B C}$ & $9.19 \pm 0.21^{a, b}$ & $11.18 \pm 0.47^{a, A}$ \\
\hline & Clove-2MIC & $7.16 \pm 0.14^{\mathrm{a}, \mathrm{D}}$ & $8.26 \pm 0.19^{a, c}$ & $9.24 \pm 0.11^{a, B}$ & $11.34 \pm 0.14^{\mathrm{a}, \mathrm{A}}$ \\
\hline & Clove-4MIC & $7.09 \pm 0.06^{a, c}$ & $8.07 \pm 0.41^{\mathrm{a}, \mathrm{BC}}$ & $9.09 \pm 0.05^{a, A B}$ & $10.02 \pm 0.33^{a, A}$ \\
\hline \multirow[t]{5}{*}{ Coliform (log cfu/g) } & Control & $4.41 \pm 0.04^{a, A}$ & $4.65 \pm 0.49^{a, A}$ & $5.01 \pm 0.34^{a, A}$ & $6.07 \pm 0.19^{a, A}$ \\
\hline & Thyme-2MIC & $4.56 \pm 0.08^{a, A}$ & $4.74 \pm 0.06^{\mathrm{a}, \mathrm{A}}$ & $4.79 \pm 0.44^{a, A}$ & $5.89 \pm 0.21^{\mathrm{a}, \mathrm{A}}$ \\
\hline & Thyme-4MIC & $4.50 \pm 0.25^{\mathrm{a}, \mathrm{A}}$ & $4.28 \pm 0.03^{a, A}$ & $4.74 \pm 0.43^{\mathrm{a}, \mathrm{A}}$ & $5.69 \pm 0.26^{a, A}$ \\
\hline & Clove-2MIC & $4.42 \pm 0.26^{a, A}$ & $4.62 \pm 0.12^{a, A}$ & $4.59 \pm 0.63^{a, A}$ & $5.32 \pm 0.30^{\mathrm{ab}, \mathrm{A}}$ \\
\hline & Clove-4MIC & $4.36 \pm 0.35^{a, A}$ & $4.57 \pm 0.18^{a, A}$ & $4.39 \pm 0.17^{a, A}$ & $4.10 \pm 0.46^{b, A}$ \\
\hline \multirow[t]{5}{*}{ Yeast and molds (log cfu/g) } & Control & $6.30 \pm 0.43^{a, c}$ & $7.71 \pm 0.23^{a, B C}$ & $9.29 \pm 0.00^{\mathrm{ab}, \mathrm{B}}$ & $11.63 \pm 0.43^{a, A}$ \\
\hline & Thyme-2MIC & $6.23 \pm 0.35^{a, c}$ & $7.31 \pm 0.11^{a, c}$ & $9.41 \pm 0.00^{a, B}$ & $11.82 \pm 0.45^{\mathrm{a}, \mathrm{A}}$ \\
\hline & Thyme-4MIC & $6.06 \pm 0.36^{a, c}$ & $7.70 \pm 0.27^{a, B C}$ & $9.18 \pm 0.00^{a b, B}$ & $11.22 \pm 0.53^{a, A}$ \\
\hline & Clove-2MIC & $6.04 \pm 0.19^{a, D}$ & $7.50 \pm 0.25^{a, c}$ & $9.22 \pm 0.00^{a b, B}$ & $11.35 \pm 0.00^{a, A}$ \\
\hline & Clove-4MIC & $6.42 \pm 0.09^{a, c}$ & $7.33 \pm 0.21^{\mathrm{a}, \mathrm{c}}$ & $8.81 \pm 0.25^{b, B}$ & $10.09 \pm 0.11^{\mathrm{a}, \mathrm{A}}$ \\
\hline \multirow[t]{5}{*}{ Psychrotrophs (log cfu/g) } & Control & $7.05 \pm 0.01^{a, c}$ & $8.01 \pm 0.23^{a, B C}$ & $8.95 \pm 0.00^{c, B}$ & $11.64 \pm 0.58^{a_{a} A}$ \\
\hline & Thyme-2MIC & $6.87 \pm 0.18^{a, c}$ & $7.54 \pm 0.12^{a, c}$ & $9.24 \pm 0.00^{b, B}$ & $11.85 \pm 0.44^{\mathrm{a}, \mathrm{A}}$ \\
\hline & Thyme-4MIC & $6.99 \pm 0.02^{a, c}$ & $7.89 \pm 0.21^{\mathrm{a}, \mathrm{BC}}$ & $8.92 \pm 0.00^{c, B}$ & $11.27 \pm 0.42^{a, A}$ \\
\hline & Clove-2MIC & $7.02 \pm 0.08^{a, c}$ & $7.65 \pm 0.24^{a, c}$ & $9.20 \pm 0.00^{b, B}$ & $11.38 \pm 0.21^{\mathrm{a}, \mathrm{A}}$ \\
\hline & Clove-4MIC & $7.01 \pm 0.01^{\mathrm{a}, \mathrm{B}}$ & $7.74 \pm 0.48^{\mathrm{a}, \mathrm{B}}$ & $9.32 \pm 0.03^{\mathrm{a}, \mathrm{A}}$ & $10.15 \pm 0.34^{\mathrm{a}, \mathrm{A}}$ \\
\hline
\end{tabular}

a-c Different letters indicate significant differences $(P<0.05)$ within each storage time.

A-D Different letters indicate significant differences $(P<0.05)$ within each treatment.

cfu, colony-forming units; MIC, minimum inhibitory concentration.

storage period TCC increased for control, thyme (2MIC and $4 \mathrm{MIC})$ and clove (2MIC) treated samples. However, a 0.26 log cycle reduction was observed for the clove (4MIC) treated sample at the end of 9 days. The results of TCC indicated that clove EO inhibited the growth of coliform bacteria during 9-day period (Table 4).

The initial numbers of yeasts and molds were almost the same with approximately $6 \mathrm{log} / \mathrm{g}$ for all groups of samples. The number of yeasts and molds of control and treated samples increased dramatically during 9 days of storage (Table 4). Although the load of all samples exceeded to 11 $\mathrm{log} / \mathrm{g}$ at the end of 9 days, clove (4MIC) treated sample increased up to $10.09 \mathrm{log} / \mathrm{g}$ (Table 4 ). There was no great difference between the number of yeasts and molds found in samples.

A dramatic growth of psychrotrophic organisms was observed during 9 days of storage for all groups of samples (Table 4). Counting of mesophilic bacteria in ground beef is the useful tool for determining post-processing contamination level, monitoring microbial quality and shelf life evaluation; however, the most prominent microbial group responsible for the spoilage of ground beef as seen also in our results is the psychrotrophs. There was no significant difference between the number of psychrotrophs in the samples. However, control, thyme (2MIC and 4MIC) and clove (2MIC) EO-treated samples showed growth ended up with $\sim 11 \mathrm{log} / \mathrm{g}$, whereas clove (4MIC) ended up with a $\sim 10$ $\log / \mathrm{g}$ of psychrotrophic organisms (Table 4).
Our findings represented that clove EO restricted the growth of Sa. typhimurium and coliform bacteria comparing with thyme EO with $4 \mathrm{MIC}$ value. It was not seemed to be inhibiting the aerobic mesophiles, yeasts and molds and also psychrotrophic microorganisms. This finding confirms the statement of the thyme, and clove EOs have significant bacteriostatic/inhibiting properties for pathogenic and spoilage microorganisms and as a result they were less effective as food preservative in food (Bensid et al. 2014). However, their growth was lesser than the control sample.

\section{Effect of EOs on Lipid Oxidation in Minced Beef}

The oxidation conditions of minced meat samples were evaluated by observing the absorbance at $532 \mathrm{~nm}$. TBA values were determined using the thiobarbituric acid reactive substances assay (Fig. 1b). Measurements were obtained over 9 days of storage, and TBA values of control showed a rapid increase with increasing storage time. TBA values of all treatments on day 0 were significantly lower $(P<0.05)$ than those for the control sample (Fig. 1b). Moreover, treatment samples had significantly lower $(P<0.05)$ TBA values than control at each day of testing throughout sixth and ninth days of the storage period. Although there was no significant difference among treated samples, each treatment showed significant reduction $(P<0.05)$ comparing with 


\begin{tabular}{|c|c|c|c|c|c|}
\hline \multirow[b]{2}{*}{ Samples } & \multicolumn{5}{|c|}{ Storage time (days) } \\
\hline & & 0 & 3 & 6 & 9 \\
\hline \multirow{3}{*}{$\begin{array}{l}\text { Control (with } \\
\text { inoculum) }\end{array}$} & $L^{*}$ & $49.57 \pm 0.28^{\mathrm{a}, \mathrm{A}}$ & $50.03 \pm 0.18^{\mathrm{a}, \mathrm{A}}$ & $50.89 \pm 0.15^{a, A}$ & $50.79 \pm 1.64^{\mathrm{a}, \mathrm{A}}$ \\
\hline & $a^{*}$ & $19.77 \pm 1.53^{\mathrm{a}, \mathrm{A}}$ & $18.02 \pm 0.62^{\mathrm{a}, \mathrm{A}}$ & $16.70 \pm 0.21^{\mathrm{a}, \mathrm{A}}$ & $14.81 \pm 1.21^{\mathrm{a}, \mathrm{A}}$ \\
\hline & $b^{*}$ & $10.09 \pm 0.09^{\mathrm{a}, \mathrm{A}}$ & $10.40 \pm 0.07^{\mathrm{a}, \mathrm{A}}$ & $10.49 \pm 0.4^{\mathrm{a}, \mathrm{A}}$ & $9.44 \pm 0.57^{\mathrm{a}, \mathrm{A}}$ \\
\hline \multirow[t]{3}{*}{ Thyme-2MIC } & $L^{*}$ & $49.91 \pm 0.45^{\mathrm{a}, \mathrm{A}}$ & $49.85 \pm 0.46^{\mathrm{a}, \mathrm{A}}$ & $49.23 \pm 0.07^{\mathrm{a}, \mathrm{A}}$ & $51.19 \pm 0.62^{\mathrm{a}, \mathrm{A}}$ \\
\hline & $a^{*}$ & $19.61 \pm 2.26^{\mathrm{a}, \mathrm{A}}$ & $16.26 \pm 5.08^{\mathrm{a}, \mathrm{A}}$ & $16.76 \pm 0.91^{\mathrm{a}, \mathrm{A}}$ & $16.54 \pm 3.65^{\mathrm{a}, \mathrm{A}}$ \\
\hline & $b^{*}$ & $9.06 \pm 0.85^{\mathrm{a}, \mathrm{A}}$ & $10.21 \pm 1.74^{\mathrm{a}, \mathrm{A}}$ & $10.64 \pm 0.57^{\mathrm{a}, \mathrm{A}}$ & $10.46 \pm 0.43^{\mathrm{a}, \mathrm{A}}$ \\
\hline \multirow[t]{3}{*}{ Thyme-4MIC } & $L^{*}$ & $49.82 \pm 0.22^{\mathrm{a}, \mathrm{A}}$ & $50.29 \pm 0.16^{\mathrm{a}, \mathrm{A}}$ & $50.24 \pm 1.27^{\mathrm{a}, \mathrm{A}}$ & $49.08 \pm 1.79^{\mathrm{a}, \mathrm{A}}$ \\
\hline & $a^{*}$ & $19.60 \pm 0.74^{\mathrm{a}, \mathrm{A}}$ & $16.88 \pm 0.69^{\mathrm{a}, \mathrm{A}}$ & $18.83 \pm 1.34^{\mathrm{a}, \mathrm{A}}$ & $18.50 \pm 0.96^{a, A}$ \\
\hline & $b^{*}$ & $9.72 \pm 0.18^{\mathrm{a}, \mathrm{A}}$ & $10.73 \pm 0.32^{\mathrm{a}, \mathrm{A}}$ & $10.70 \pm 0.47^{\mathrm{a}, \mathrm{A}}$ & $9.99 \pm 0.68^{\mathrm{a}, \mathrm{A}}$ \\
\hline \multirow[t]{3}{*}{ Clove-2MIC } & $L^{*}$ & $49.35 \pm 0.29^{\mathrm{a}, \mathrm{A}}$ & $50.96 \pm 1.32^{\mathrm{a}, \mathrm{A}}$ & $50.36 \pm 0.64^{\mathrm{a}, \mathrm{A}}$ & $51.00 \pm 0.74^{\mathrm{a}, \mathrm{A}}$ \\
\hline & $a^{*}$ & $20.80 \pm 0.90^{\mathrm{a}, \mathrm{A}}$ & $17.56 \pm 1.04^{\mathrm{a}, \mathrm{A}}$ & $18.57 \pm 0.99^{\mathrm{a}, \mathrm{A}}$ & $18.44 \pm 0.99^{\mathrm{a}, \mathrm{A}}$ \\
\hline & $b^{*}$ & $9.89 \pm 0.30^{\mathrm{a}, \mathrm{B}}$ & $10.69 \pm 0.12^{\mathrm{a}, \mathrm{AB}}$ & $10.95 \pm 0.12^{\mathrm{a}, \mathrm{A}}$ & $11.35 \pm 0.12^{\mathrm{a}, \mathrm{A}}$ \\
\hline \multirow[t]{3}{*}{ Clove-4MIC } & $L^{*}$ & $48.65 \pm 1.25^{\mathrm{a}, \mathrm{A}}$ & $50.60 \pm 1.35^{\mathrm{a}, \mathrm{A}}$ & $49.63 \pm 0.82^{\mathrm{a}, \mathrm{A}}$ & $51.12 \pm 0.62^{\mathrm{a}, \mathrm{A}}$ \\
\hline & $a^{*}$ & $18.29 \pm 0.83^{\mathrm{a}, \mathrm{A}}$ & $19.38 \pm 0.45^{\mathrm{a}, \mathrm{A}}$ & $19.24 \pm 2.32^{\mathrm{a}, \mathrm{A}}$ & $17.60 \pm 4.45^{\mathrm{a}, \mathrm{A}}$ \\
\hline & $b^{*}$ & $9.37 \pm 0.01^{\mathrm{a}, \mathrm{A}}$ & $10.48 \pm 0.66^{\mathrm{a}, \mathrm{A}}$ & $11.28 \pm 0.17^{\mathrm{a}, \mathrm{A}}$ & $11.09 \pm 0.58^{\mathrm{a}, \mathrm{A}}$ \\
\hline
\end{tabular}

TABLE 5. CHANGES IN COLOR OF MINCED BEEF SAMPLES DURING STORAGE AT 4C

The values were expressed as mean \pm standard deviation, $n=3$.

$A, B$ Different letters indicate significant differences $(P<0.05)$ within each treatment.

a-b Means having different letters indicate significant difference at $p<0.05$ within each storage time.

MIC, minimum inhibitory concentration.

control (Fig. 1b). The results indicated that thyme (2MIC and 4MIC) and clove (2MIC and 4MIC) EOs retarded lipid oxidation during 9 days of storage at $4 \mathrm{C}$. Although clove EO showed the higher in vitro antioxidant activity than thyme EO (Table 3) in minced meat application, both of the EO treatments showed significant reduction $(P<0.05)$ in TBA value comparing with control. Lipid oxidation in food products is considered to be one of the important factors limiting product quality and acceptability due to the production of potentially toxic reactive oxygen species and offflavors from unsaturated fatty acids (Cui et al. 2012). Antioxidant activity of various EOs and components has been determined using TBA assay, which is an index of secondary lipid oxidation measuring malondialdehyde in both model and real meat systems, showing a potential for protection of meat from oxidation (Guillén-Sans and Guzmán-Chozas 1998; Ruberto and Baratta 1999; Tanabe et al. 2002; Fasseas et al. 2007; Bensid et al. 2014). Protective effectiveness of EOs on meat oxidation stability was also shown in this study (Fig. 1b), which are in agreement with those of previous findings.

\section{Effect of EOs on Color in Minced Beef}

The objective color parameters $L^{\star}, a^{\star}$ and $b^{\star}$ during storage according to different treatments evaluated are shown in Table 5. As seen in the lightness there was no significant darkening or browning in color due to metmyoglobin formation between all group of samples in terms of both EO treatments and storage time (Table 5). The initial $L^{\star}$ values were maintained during the storage period. $a^{*}$ value of control sample showed a dramatic reduction following the time period of storage. There was no significant difference among $a^{\star}$ values of control and EO-treated samples throughout the storage period (Table 5 ). However, $a^{\star}$ value was maintained during 9 days of storage in clove EO (4MIC) treated samples comparing with control sample. There was also no significant difference between $b^{\star}$ values of treated samples (Table 5 ). But $b^{\star}$ values showed a significant $(P<0.05)$ alteration over the time period (Table 5$)$. The color parameters lightness, redness and yellowness were not significantly affected when compared with control by the addition of EOs; this fact suggests that no characteristic color alteration means no rejection from customers.

\section{CONCLUSION}

The biological activities of natural compounds such as EOs are highly affected by their chemical compositions. EOs are complex natural mixtures that behind their major and minor components are also effective on the biological activities, possibly by producing a synergistic effect between other components. EOs are complex mixtures. Biological activities are affected by minor components possibly by producing a synergistic effect, beside the major ones. Results showed that thyme and clove EOs showed strong antimicrobial activity against all the tested spoilage and pathogenic bacteria with different MIC values. Therefore, EOs could have potential applications in meat industries. Although thyme and clove EOs restricted the growth of 
Sa. typhimurium and Coliform bacteria, it was not seemed to be inhibiting the aerobic mesophiles, yeasts and molds and also psychrotrophic microorganisms in ground beef application study. As it was demonstrated in the results, EOs were not effective negatively on color parameters. Thus, both $L^{\star}$ and $a^{*}$ values were maintained during the refrigeration storage period. This study showed that the most prominent and featured effect of EOs was the antioxidant capacity in the ground beef meat application study.

\section{CONFLICT OF INTEREST}

The authors declare that they have no conflict of interest.

\section{ACKNOWLEDGMENTS}

This research was supported by the Izmir Institute of Technology Scientific Research Project Fund (Iztech BAP project no: 2012-07). GC-MS analyses were performed in Environmental Development Application and Research Center of Izmir Institute of Technology.

\section{REFERENCES}

AIT-OUAZZOU, A., LORAN, S., BAKKALI, M., LAGLAOUI, A., ROTA, C., HERRERA, A., PAGAN, R. and CONCHELLO, P. 2011. Chemical composition and antimicrobial activity of essential oils of Thymus algeriensis, Eucalyptus globulus and Rosmarinus officinalis from Morocco. J. Sci. Food Agric. 91, 2643-2651.

BARBOSA, L.N., RALL, V.L.M., FERNANDES, A.A.H., USHIMARU, P.I., PROBST, I.S. and FERNANDES, A., JR. 2009. Essential oils against foodborne pathogens and spoilage bacteria in minced meat. Foodborne Pathog. Dis. 6, 725-728.

BAYDAR, H., SAĞDIÇ, O., ÖZKAN, G. and KARADOĞAN, T. 2004. Antibacterial activity and composition of essential oils from Origanum, Thymbra and Satureja species with commercial importance in Turkey. Food Control 15, 169-172.

BENSID, A., UCAR, Y., BENDEDDOUCHE, B. and ÖZOGUL, F. 2014. Effect of the icing with thyme, oregano and clove extracts on quality parameters of gutted and beheaded anchovy (Engraulis encrasicolus) during chilled storage. Food Chem. 145, 681-686.

BLESSINGTON, T., MITCHAM, E.J. and HARRIS, L.J. 2012. Survival of Salmonella enterica, Escherichia coli O157:H7, and Listeria monocytogenes on inoculated walnut kernels during storage. J. Food Prot. 75, 245-254.

BURT, S.A. 2004. Essential oils: Their antibacterial properties and potential applications in foods - a review. Int. J. Food Microbiol. 94, 223-253.

BURT, S.A., VAN DER ZEE, R., KOETS, A.P., DE GRAAFF, A.M., VAN KNAPEN, F., GAASTRA, W., HAAGSMAN, H.P. and VELDHUIZEN, E.J.A. 2007. Carvacrol induces heat shock protein 60 and inhibits synthesis of flagellin in Escherichia coli O157:H7. Appl. Environ. Microbiol. 73, 4484-4490.

CUI, Y., OH, Y.J., LIM, J., YOUN, M., LEE, I., PAK, H.K., PARK, W., JO, W. and PARK, S. 2012. AFM study of the differential inhibitory effects of the green tea polyphenol

(-)-epigallocatechin-3-gallate (EGCG) against Gram-positive and Gram-negative bacteria. Food Microbiol. 29, 80-87.

DELGADO ADÁMEZ, J., GAMERO SAMINO, E., VALDÉS SÁNCHEZ, E. and GONZÁLEZ-GÓMEZ, D. 2012. In vitro estimation of the antibacterial activity and antioxidant capacity of aqueous extracts from grape-seeds (Vitis vinifera L.). Food Control 24, 136-141.

DJENANE, D., AÏDER, M., YANGÜELA, J., IDIR, L., GÓMEZ, D. and RONCALÉS, P. 2012. Antioxidant and antibacterial effects of Lavandula and Mentha essential oils in minced beef inoculated with E. coli $\mathrm{O} 157: \mathrm{H} 7$ and S. aureus during storage at abuse refrigeration temperature. Meat Sci. 92, 667-674.

DORMAN, H.J.D., FIGUEIREDO, A.C., BARROSO, J.G. and DEANS, S.G. 2000. In vitro evaluation of antioxidant activity of essential oils and their components. Flav. Frag. J. 15, $12-16$.

ECONOMOU, G., PANAGOPOULOS, G., TARANTILIS, P., KALIVAS, D., KOTOULAS, V., TRAVLOS, I.S., POLYSIOU, M. and KARAMANOS, A. 2011. Variability in essential oil content and composition of Origanum hirtum L., Origanum onites L., Coridothymus capitatus (L.) and Satureja thymbra L. populations from the Greek island Ikaria. Ind. Crops Prod. 33, 236-241.

FASSEAS, M.K., MOUNTZOURIS, K.C., TARANTILIS, P.A., POLISSIOU, M. and ZERVAS, G. 2007. Antioxidant activity in meat treated with oregano and sage essential oils. Food Chem. 106, 1188-1194.

FDA 2013. CFR - Code of Federal Regulations title 21, volume 3, revised as of April 1, part 182 - substances generally recognized as safe (GRAS) subpart A - general provisions sec. 182.20 essential oils, oleoresins (solvent-free), and natural extractives. http://www.accessdata.fda.gov/scripts/cdrh/cfdocs/ cfcfr/CFRSearch.cfm?fr=182.20 (accessed April 14, 2013).

FLESSA, S., LUSK, D.M. and HARRIS, L.J. 2005. Survival of Listeria monocytogenes on fresh and frozen strawberries. Int. J. Food Microbiol. 101, 255-262.

GOURINE, N., YOUSFI, M., BOMBARDA, I., NADJEMI, B., STOCKER, P. and GAYDOU, E.M. 2010. Antioxidant activities and chemical composition of essential oil of Pistacia atlantica from Algeria. Ind. Crops Prod. 31, 203-208.

GUAN, W., LI, S., YAN, R., TANG, S. and QUAN, C. 2007. Comparison of essential oils of clove buds extracted with supercritical carbon dioxide and other three traditional extraction methods. Food Chem. 101, 1558-1564.

GUILLÉN-SANS, R. and GUZMÁN-CHOZAS, M. 1998. The thiobarbituric acid (TBA) reaction in foods: A review. Crit. Rev. Food Sci. Nutr. 38, 315-330. 
GUTIERREZ, J., BARRY-RYAN, C. and BOURKE, P. 2008. The antimicrobial efficacy of plant essential oil combinations and interactions with food ingredients. Int. J. Food Microbiol. 124, 91-97.

GUTIERREZ, J., BARRY-RYAN, C. and BOURKE, P. 2009. Antimicrobial activity of plant essential oils using food model media: Efficacy, synergistic potential and interactions with food components. Food Microbiol. 26, 142-150.

GÜLÇIN, İ., GÜNGÖR ŞAT, İ., BEYDEMIR, Ş., ELMASTAŞ, M. and KÜFREVIOĞLU, Ö.İ. 2004. Comparison of antioxidant activity of clove (Eugenia caryophyllata Thunb) buds and lavender (Lavandula stoechas L.). Food Chem. 87, 393-400.

HAYOUNI, A., CHRAIEF, I., ABEDRABBA, M., BOUIX, M., LEVEAU, J., MOHAMMED, H. and HAMDI, M. 2008. Tunisian Salvia officinalis L. and Schinus molle L. essential oils: Their chemical compositions and their preservative effects against Salmonella inoculated in minced beef meat. Int. J. Food Microbiol. 125, 242-251.

HOSNI, K., HASSEN, I., CHAÂBANE, H., JEMLI, M., DALLALI, S., SEBEI, H. and CASABIANCA, H. 2013. Enzyme-assisted extraction of essential oils from thyme (Thymus capitatus L.) and rosemary (Rosmarinus officinalis L.): Impact on yield, chemical composition and antimicrobial activity. Ind. Crops Prod. 47, 291-299.

ICMSF 1986. Microorganisms in Foods, Sampling for microbiological analysis: Principles and applications, University of Toronto Press, Toronto.

JAYASENA, D.D. and JO, C. 2013. Essential oils as potential antimicrobial agents in meat and meat products: A review. Trends Food Sci. Technol. 34, 96-108.

KLANČNIK, A., PISKERNIK, S., JERŠEK, B. and MOŽINA, S.S. 2010. Evaluation of diffusion and dilution methods to determine the antibacterial activity of plant extracts. J. Microbiol. Methods 81, 121-126.

LEE, K.-G. and SHIBAMOTO, T. 2001. Antioxidant property of aroma extract isolated from clove buds [Syzygium aromaticum (L.) Merr. et Perry]. Food Chem. 74, 443-448.

LUCERA, A., COSTA, C., CONTE, A. and DEL NOBILE, M.A. 2012. Food applications of natural antimicrobial compounds. Front. Microbiol. 3, 1-13.

MARTINI, H., WEIDENBORNER, M., ADAMS, S. and KUNZ, B. 1996. Eugenol and carvacrol: The main fungicidal compounds in clove and savory. Ital. J. Food Sci. 8 , 63-67.

NAPOLI, E.M., CURCURUTO, G. and RUBERTO, G. 2010. Screening of the essential oil composition of wild Sicilian thyme. Biochem. Syst. Ecol. 38, 816-822.

OJEDA-SANA, A.M., VAN BAREN, C.M., ELECHOSA, M.A., JUÁREZ, M.A. and MORENO, S. 2013. New insights into antibacterial and antioxidant activities of rosemary essential oils and their main components. Food Control 31, 189-195.

PETKAR, A., ALALI, W.Q., HARRISON, M.A. and BEUCHAT, L.R. 2011. Survival of Salmonella in organic and conventional broiler feed as affected by temperature and water activity. Agric. Food Anal. Bacteriol. 1, 175-185.
POLITEO, O., JUKIC, M. and MILOS, M. 2010. Comparison of chemical composition and antioxidant activity of glycosidically bound and free volatiles from clove (Eugenia caryophyllata thunb.). J. Food Biochem. 34, 129-141.

RAMOS, C., TEIXEIRA, B., BATISTA, I., MATOS, O., SERRANO, C., NENG, N.R., NOGUEIRA, J.M.F., NUNES, M.L. and MARQUES, A. 2012. Antioxidant and antibacterial activity of essential oil and extracts of bay laurel Laurus nobilis Linnaeus (Lauraceae) from Portugal. Nat. Prod. Res. 26, 518-529.

RUBERTO, G. and BARATTA, M.T. 1999. Antioxidant activity of selected essential oil components in two lipid model systems. Food Chem. 69, 167-174.

SAFAEI-GHOMI, J., EBRAHIMABADI, A.H., DJAFARI-BIDGOLI, Z. and BATOOLI, H. 2009. GC/MS analysis and in vitro antioxidant activity of essential oil and methanol extracts of Thymus caramanicus Jalas and its main constituent carvacrol. Food Chem. 115, 1524-1528.

SCHWARZ, K., BERTELSEN, G., NISSEN, L.R., GARDNER, P.T., HEINONEN, M.I., HOPIA, A., HUYNH-BA, T., LAMBELET, P., MCPHAIL, D., SKIBSTED, L.H. et al. 2001. Investigation of plant extracts for the protection of processed foods against lipid oxidation. Comparison of antioxidant assays based on radical scavenging, lipid oxidation and analysis of the principal antioxidant compounds.

Eur. Food Res. Technol. 212, 319-328.

SIMPSON, C.A., GEORNARAS, I., YOON, Y., SCANGA, J.A., KENDALL, P.A. and SOFOS, J.N. 2008. Effect of inoculum preparation procedure and storage time and temperature on the fate of Listeria monocytogenes on inoculated salami. J. Food Prot. 71, 494-501.

SLINKARD, K. and SINGLETON, V.L. 1977. Total phenol analysis: Automation and comparison with manual methods. Am. J. Enol. Vitic. 28, 49-55.

SOKMEN, A., GULLUCE, M., ASKIN AKPULAT, H., DAFERERA, D., TEPE, B., POLISSIOU, M., SOKMEN, M. and SAHIN, F. 2004. The in vitro antimicrobial and antioxidant activities of the essential oils and methanol extracts of endemic Thymus spathulifolius. Food Control 15, 627-634.

SOLOMAKOS, N., GOVARIS, A., KOIDIS, P. and BOTSOGLOU, N. 2008. The antimicrobial effect of thyme essential oil, nisin and their combination against Escherichia coli O157:H7 in minced beef during refrigerated storage. Meat Sci. 80, 159-166.

TANABE, H., YOSHIDA, M. and TOMITA, N. 2002. Comparison of the antioxidant activities of 22 commonly used culinary herbs and spices on the lipid oxidation of pork meat. Anim. Sci. J. 73, 389-393.

TEPE, B., SOKMEN, M., AKPULAT, H.A., DAFERERA, D., POLISSIOU, M. and SOKMEN, A. 2005. Antioxidative activity of the essential oils of Thymus sipyleus subsp. sipyleus var. sipyleus and Thymus sipyleus subsp. sipyleus var. rosulans. J. Food Eng. 66, 447-454. 
THAIPONG, K., BOONPRAKOB, U., CROSBY, K., CISNEROS-ZEVALLOS, L. and HAWKINS, B.D. 2006. Comparison of ABTS, DPPH, FRAP, and ORAC assays for estimating antioxidant activity from guava fruit extracts. J. Food Compost. Anal. 19, 669-675.

UHART, M., MAKS, N. and RAVISHANKAR, S. 2006. Effect of spices on growth and survival of Salmonella typhimurium DT 104 in ground beef stored at 4 and 8C. J. Food Saf. 26, 115-125.

VERMA, R.S., PADALIA, R.C., CHANOTIYA, C.S. and CHAUHAN, A. 2010. Chemical investigation of the essential oil of Thymus linearis (Benth. ex Benth) from western Himalaya, India. Nat. Prod. Res. 24, 1890-1896.

VIUDA-MARTOS, M., RUIZ NAVAJAS, Y., SÁNCHEZ ZAPATA, E., FERNÁNDEZ-LÓPEZ, J. and PÉREZ-ÁLVAREZ, J.A. 2010. Antioxidant activity of essential oils of five spice plants widely used in a Mediterranean diet. Flav. Frag. J. 25, 13-19.

WANG, H.F., WANG, Y.K. and YIH, K.H. 2008. DPPH free-radical scavenging ability, total phenolic content, and chemical composition analysis of forty-five kinds of essential oils. J. Cosmet. Sci. 59, 509-522. 